at the academy, helped Ward set up the exhibits. Soon afterwards he took his first permanent job with Ward in Rochester, where he published a Catalogue of Specimens of Mollusca and Brachiopoda for Sale at Ward's, Ward supplying biological material to various universities, schools, museums and private collectors.

Milwaukee decided to found a permanent museum with Ward's special exhibit as a basis and Wheeler returned home to work there, and soon became director. In this new museum his friend and colleague Carl Akeley created the first museum habitat group-a scene of muskrats in a pond. Akeley's later work became a feature in the Field Museum, Chicago, and of the American Museum of Natural History, New York, which set the trend towards realism now followed by many museums.

In the summer of 1889, Wheeler visited the new laboratory at Woods Hole, directed by his former teacher at the German-English Academy in Milwaukee, C. O. Whitman. In this stimulating environment he met biologists such as T. H. Morgan, J. Loeb, E. G. Conklin and H. F. Osborn and many others, and developed a love for marine animals. In 1890 he followed C. O. Whitman to the newly founded Clark University in Worcester (Massachusetts) where he obtained his doctorate for a thesis on the embryology of insects in which he described in detail the embryonic writhings - blastokinesis - which are peculiar to insects with yolky eggs.

By 1892 he was teaching in Chicago and from there he visited Europe, spending some months with Boveri in Würzburg where he used the latest methods of section cutting to study the excretory system of the lamprey. $\mathrm{He}$ continued his summer visits to Woods Hole and in 1894 published a detailed study of the curious sex change in the marine worm Myzostoma. It was his move to Austin, Texas, in 1899 which brought him into contact with the ants which he studied with such fascination in later years. In 1908 he became professor of economic entomology and later dean at the Bussey Institution in Harvard. These years at the Bussey were the most influential in his life and he stayed there until his retirement in 1934 , to die three years later.

Wheeler's teaching at so many new institutions had considerable influence on the development of biology. His books, Ants (1910) and The Social Insects (1928), were widely read by biologists. These books emphasized that what the animal really did was at least as important as its structure alone; so was born the subject which he termed ethology which has more recently been developed so successfully by Lorenz, Tinbergen and others.

A collection of essays, Foibles of In- sects and Men (1928), in which his barbed shafts of wit, "liberally suffused with formic acid", aimed largely at "the stuffy and the solemn, not excluding professors of biology", reached the widest circle of readers. Wheeler himself did not rate the value of his scientific contributions in relation to their popularity; he took the greatest pride in his taxonomic work on various groups of flies and on the ants.

Readers of this book will ponder on the contrast between Wheeler's time and ours. Who nowadays could change his job so frequently and work in so many institutions and make such long and profitable trips abroad? Who could now produce important publications in so many biological fields?

Wheeler himself had the gift of clear exposition. His biographers share this ability so that the book can be read, or dipped into, with interest and enjoyment. The book includes twenty-one illustrations of insects and men, a list of Wheeler's 680 publications and an index which will greatly help readers to piece together the strands which make up this book.

G. C. VARLEY

\section{Below the Sea Bed}

200,000,000 Years Beneath the Sea. By Peter Briggs. Pp. 228. (Holt, Rinehart and Winston: New York, Chicago and San Francisco, September 1971.) \$7.95.

THE author of this book has considerable experience at sea and as a science journalist. The title of his book refers to the oldest sediments recovered by coring deep holes drilled into the ocean floor during the past three years by the very advanced US exploration vessel Ocean Challenger. The book tells chiefly about the ship and the work at sea but the author sets his story against a background of all the evidence and ideas that have led to the new theory of seafloor spreading. It describes how the theory has evolved from topographic, seismic and magnetic studies of the deep ocean floor, particularly of the mid-ocean ridges and their rift valleys in which the continuing upwelling of basalt forms the new ocean floor, and continues with the concept of moving plates of seafloor and continental crustal material now used to explain the great mountain ranges, deep sea trenches, vulcanism and earthquakes. Where they collide, one sinks below the other and where ocean floor moves towards the land as along the west coast of America, seafloor material is subthrusted below the land. Some of the metalliferous provinces and ore concentrations are being explained in these terms, and from the practical as well as scientific point of view study of the sediments and rocks below the sea bed has become exciting and important.
After a general introduction to the history and background geology, the author tells of the now almost legendary American Miscellaneous Society and its drilling committee whose informal and formal discussions and negotiations led to the Mohole Project and to experimental drilling in deep water. The author implies that the successful investigation of the sediments was one of the factors which diverted interest from the more spectacular project of drilling right through the Earth's crust. It established the feasibility of the Deep Sea Drilling Project that followed, and provided much of the necessary design data. The new project is managed by the Scripps Institution, but the ship is run by Global Marine Inc, a sizable commercial oil-drilling concern which achieves real economy by choosing good men and paying and treating them exceptionally well. They work hard and are unquestionably competent and interested in new methods and equipment. The whole ship's company, about seventy in all, is changed at the end of each voyage of about two months and the officers and crew alternate one voyage on and the next on vacation. The decisions are made promptly by the specialists directly concerned, and who best understand the scientists, sailors and work at sea. There is none of the over centralized regulation, and insistence on controlling everything of many government funded projects.

The book describes the day to day successes and difficulties of thirteen voyages, equivalent to well over two trips round the world. The reader gets an impression of about two hundred deep drillings, the longest drill string being more than 4 miles and the deepest sediment penetration 3,231 feet. Drilling was sometimes stopped by a hard layer of flinty rock called chert which wears out the diamond bits after a few feet of drilling, but a method of reentering the same hole has been worked out and tried successfully at a depth of 2 miles. A bit-changing operation might take 15 hours. More than three hundred US scientists have been concerned in the project and perhaps a tenth of this number have been from abroad. The cost for $4 \frac{1}{2}$ years work is to be nearly 35 million dollars.

The author gives a lively impression of how the programmes are planned and executed. He emphasizes the value of invertebrate palaeontology which seemed a very remote sort of science before the days of oil wells, and which now provides key personnel for the work at sea. Geologists and scientists who have worked at sea will probably be the most appreciative and satisfied readers of the book but it can be recommended to anybody with scientific interests.

G. E. R. DEACON 